\title{
Post-training Knowledge and Attitude Assessment of the Women Entrepreneurs towards Mushroom Cultivation
}

\author{
Sonam $^{1 *}$, Shishir Kala ${ }^{1}$, P. Prabhakar² and Mamoni Banerjee ${ }^{2}$ \\ ${ }^{1}$ Department of Family Resource Management, Dr. Rajendra Prasad Central Agricultural University, Pusa, Samastipur, India \\ ${ }^{2}$ Rajendra Mishra School of Engineering Entrepreneurship, Indian Institute of Technology Kharagpur, Kharagpur, India \\ "Correspondence: sonamprabhakar1@gmail.com (ORCID ID: 0000-0001-5911-6129)
}

Paper No. 904

Received: $17-03-2021$

Revised: 24-05-2021

Accepted: 14-06-2021

\begin{abstract}
Mushroom cultivation is one of the technically feasible and profitable agriculture practices which are widely recognized by researchers and farmers as the source of high income, employment, and rural development. Such employment generation and poverty alleviation ventures have a significant role in strengthening the socio-economic profile of marginalized population, especially to the rural women. Extensive training programs and workshops have been conducted by various agricultural universities, Krishi Vigyan Kendra, and research centers from time to time to skill the women for mushroom cultivation. Therefore, pieces of training have been a widely accepted strategy with high returns on investment. In this research work, the study was done to evaluate the knowledge and skill development among the women and to identify the problem and challenges towards mushroom cultivation. The majority of women respondents (75\%) have a medium level of knowledge, followed by a high level (13.3\%) and a low level of knowledge $(11.67 \%)$ of post-training mushroom cultivation. This might be due to the high interest of trainees, convenient farming, and method followed for transfer of technology. $73.33 \%$ of women have shown a favorable attitude towards mushroom cultivation. It has been observed that the mushroom cultivation training has shown a favorable attitude which helped in income generation, thus aiding financial assistance to the family.

\section{HIGHLIGHTS}

( The majority of women $(75 \%)$ have shown a medium level of knowledge towards mushroom cultivation.

( $73.33 \%$ of women have shown a favorable attitude for mushroom farming as a profitable venture.

( W Women entrepreneurs are facing the problem of storage, proper harvesting techniques, declination in nutritional value, and lack of agencies for marketing their products.
\end{abstract}

Keywords: Mushroom cultivation, entrepreneurship, skill development, rural development

Mushroom has become a popular food in present days due to its rich nutritive value and due to a good source of protein always preferred by vegetarian people. Mushroom cultivation can help in reducing poverty and strengthen livelihoods through the generation of a fast-yielding and nutritious source of food and a reliable source of income (Rachna and Sodhi 2013). Mushroom production is simple, low cost, and suitable for rural areas, is labor-intensive, and can provide employment in both the rural areas and semi-urban. Mushroom is an indoor crop grown independently of sunlight and does not require fertile land (Nagaraj et al. 2017). Using their spare time, Women can do mushroom cultivation together with household activities. This additional earning can be a perk to their family income, thus relieving much pressure on a male member of the family involved in agriculture practices. Mushroom

How to cite this article: Sonam, Kala, S., Prabhakar, P. and Banerjee, M. 2021. Post-training Knowledge and Attitude Assessment of the Women Entrepreneurs towards Mushroom Cultivation. IJAEB, 14(2): 229-234.

Source of Support: None; Conflict of Interest: None 
farming requires less capital investment, and varieties of mushrooms can be grown around the year. The mushroom substrate is clean agricultural waste material that is readily available and can be produced in temporary structures and arrangements (Shahi and Singh 2018). The production of spawn and preparation of value-added products are considered enterprise mushroom production with immense economic potential. Extensive training has generally been considered the outlet for an exchange of concepts within a community (Mazumdar et al. 2020).

Mushroom cultivation is technically feasible and an alternate way to the utilization of agricultural and industrial wastes. Extensive training and workshops have been considered as an outlet for the exchange of concepts into reality within a community. Therefore, training has been a widely accepted strategy with high returns on investment. Assessment of knowledge and skill development within the community, especially among women trainees through these outlets, is much essential for the evaluation and standardization of training programs and their modules. This assessment also brings problems and challenges which women are facing who are currently involved in mushroom cultivation practices (Kavitha et al. 2019). Thus, the present study has been done to assess the knowledge and skill development for mushroom production as an enterprise/self-employment. The training was given by the Dr. Rajendra Prasad Central Agricultural University (DRPCAU), Pusa, Samastipur, India, for the farmers, farm women, and unemployed youth to increase their income and make them self-dependent entrepreneur in the future. So, the present study was undertaken to find out the knowledge and adoption level of farm women in mushroom cultivation techniques.

\section{Methodology}

A snowball sampling technique was applied to draw the sample for the study. The study was conducted in the Samastipur district of Bihar state. A sample size comprised of 60 (sixty) respondents i.e., 15 respondents from each 4 selected villages. A respondent was elected by snowball technique. A questionnaire was designed to test the knowledge and adoption level.

\section{Knowledge of Women Mushroom Growers}

To assess the level of knowledge on mushroom cultivation, a knowledge test was specially developed for the purpose, which constituted of 56 questions with correct answers getting a score of 2 and incorrect answer getting a score of 1 ; the knowledge was administrated to the samples of respondents, the data thus got were analyzed, and the results are presented in Table 1.

\section{Level of Knowledge of Respondents about Mushroom Cultivation}

To arrive at the level of knowledge scores, the scores obtained on all the 56 questions were added, and the percentage was calculated using the following formula:

$$
\text { Knowledge index }=\frac{\text { Obtained knowledge score }}{\text { Highest obtainable score }} \times 100
$$

The knowledge score of all the 60 respondents was put in a frequency table, and their mean and S.D were computed. The score thus obtained were calculated by applying the mean \pm SD procedure to obtain low, medium, and high categories of the knowledge level of the respondents as given below:

Table 1: Knowledge and Score evaluation

\begin{tabular}{lll}
\hline S1. No. & Knowledge level & Score \\
\hline 1 & Low & Low $($ Mean $-\mathrm{SD})$ \\
2 & Medium & Medium $($ Mean \pm SD) \\
3 & High & High $($ Mean + SD) \\
\hline
\end{tabular}

\section{Methods of Measuring Respondent's Attitude}

The attitude scale used in the study was based on the five-point rating scale. The score has been assigned as 1,2,3,4 and 5 for strongly agree, agree, neutral, disagree, strongly disagree response choices, respectively, for positive statements, and these were in reverse order for negative statements. To arrive at the composite attitude score, the score obtained by each respondent for every item was summed up. The final value thus computed was reckoned to be the attitude index of the individual respondent. Based on their attitude score, the respondents were classified into three groups, namely, least favorable, favorable, and most favorable, as mentioned below. 
Table 2: Group Score obtained by an individuals

\begin{tabular}{ll}
\hline Category & Score \\
\hline Least Favourable & Up to 15 \\
Favourable & $16-19$ \\
Most Favourable & Above 19 \\
\hline
\end{tabular}

\section{RESULTS AND DISCUSSION}

Training has specific goals of improving one's capability, capacity, and performance. Trainers need to have a solid knowledge of mushroom cultivation to train others. Trainers must be capable of teaching about the mushroom, their health properties and benefits, their cultivation, processing, and how to run a mushroom production farm. More specifically, trainers need to learn about the various tasks involved in the whole process of mushroom cultivation, the various type of cultivation according to the various types of mushrooms, and the processing and transformation of cultivated mushrooms.

It is clear from Table 3 that a cent percent of respondents had received training from various sources in their business before starting mushroom cultivation. The analysis of data revealed that the majority of the mushroom growers (56.66\%) got training from DRPCAU, Pusa. It may be due to the fact that from DRPCAU, Pusa has a well-established training center and its nearness to the respondent's place. Maximum respondents $(63.33 \%)$ got training on the production of mushrooms, followed by a complete mushroom production training program on mushroom cultivation (35\%). Data of Table 3 highlights that 35 percent of respondents got training for 1 to 3 days. It was observed from the data of Table 3 a majority of the respondents $(58.34 \%)$ got training in the year 2015-2018.

The level of knowledge was measured using a knowledge test consisting of 56 questions. An attempt was made here to compute frequencies of correct answers. The results are given in Table 4 .

\section{Level of Knowledge of Respondents about Mushroom Cultivation}

It is clear from Table 5 that 75 percent of respondents possessed, medium level of knowledge which was followed by a high level of knowledge (13.33 percent), and only 11.67 percent of women had a low level of knowledge.

\section{Assessment of Attitude of Mushroom Growers}

The attitude of women mushroom growers in selected villages is computed for all the sub-

Table 3: Training Exposure of Women Mushroom Growers ( $n=60)$

\begin{tabular}{|c|c|c|c|c|}
\hline Sl. No. & Particulars & Training Details & Frequency & Percentage \\
\hline \multirow[t]{2}{*}{1} & Training Received & Yes & 60 & 100 \\
\hline & & No & - & - \\
\hline \multirow[t]{3}{*}{2} & Place of Training & DRPCAU, Pusa & 34 & 56.66 \\
\hline & & KVK under DRPCAU, Pusa & 5 & 8.34 \\
\hline & & Other & 21 & 35 \\
\hline \multirow[t]{4}{*}{3} & Mushroom Training & Spawn Preparation & 1 & 1.67 \\
\hline & & Composting & - & - \\
\hline & & Production & 38 & 63.33 \\
\hline & & $\begin{array}{l}\text { Complete Mushroom Production } \\
\text { Training Program }\end{array}$ & 21 & 35 \\
\hline \multirow[t]{3}{*}{4} & Duration of Training & 1 to 3 Days & 21 & 35 \\
\hline & & 6 to 7 Days & 19 & 31.67 \\
\hline & & Above 15 Days & 20 & 33.33 \\
\hline \multirow[t]{2}{*}{5} & No. of Training Attended & $1-2$ & 53 & 88.33 \\
\hline & & $3-4$ & 7 & 11.67 \\
\hline \multirow[t]{3}{*}{6} & Year of Training & $2007-2010$ & 10 & 16.66 \\
\hline & & 2011-2014 & 15 & 25.00 \\
\hline & & 2015-2018 & 35 & 58.34 \\
\hline
\end{tabular}


Table 4: Frequency and Percentage Distribution of Various Components of Knowledge on Mushroom Cultivation of the Respondents $(n=60)$

\begin{tabular}{|c|c|c|c|}
\hline \multirow{2}{*}{ S1. No. } & \multirow{2}{*}{ Components of Knowledge of Mushroom Cultivation } & \multicolumn{2}{|c|}{ Respondents } \\
\hline & & Frequency & Percentage \\
\hline 1 & Do you know about mushroom cultivation & 60 & 100 \\
\hline 2 & Mushroom growing is economically profitable business & 25 & 41.66 \\
\hline 4 & Mushroom cultivation is an agro based industry & 60 & 100 \\
\hline 5 & It is a women friendly avenues & 60 & 100 \\
\hline 8 & It needs less amount of money & 57 & 95 \\
\hline 9 & It gives quick return in time & 15 & 25 \\
\hline 10 & $\begin{array}{l}\text { Mushroom cultivation can be done by anybody after getting knowledge of } \\
\text { mushroom production process }\end{array}$ & 56 & 93.33 \\
\hline 11 & Climatic condition is also affecting the mushroom cultivation & 58 & 96.66 \\
\hline 14 & Oyster species is cultivated maximum in Bihar & 54 & 90 \\
\hline 15 & Oyster species is easily available in Bihar condition & 58 & 96.66 \\
\hline 16 & Button mushroom is tastier than oyster & 49 & 81.66 \\
\hline 17 & Oyster gives maximum yield & 27 & 45 \\
\hline 18 & Oyster gives maximum return (profit) & 15 & 25 \\
\hline 19 & Mushroom is eco-friendly crop & 58 & 96.66 \\
\hline 20 & Oyster is a women-friendly crop & 60 & 100 \\
\hline 21 & Do you agree that mushroom is highly nutritious food for vegetarian & 56 & 93.33 \\
\hline 22 & $\begin{array}{l}\text { If yes then protein nutrient is comparatively more available in mushrooms than } \\
\text { others }\end{array}$ & 55 & 91.66 \\
\hline 30 & Fresh air is needed for mushroom cultivation. & 56 & 93.33 \\
\hline 31 & A mushroom grows fastly in the polybag in the winter season & 48 & 80 \\
\hline 32 & $\begin{array}{l}\text { The temperature should be maintained up to } 20 \text { to } 30 \text { degrees for mushroom } \\
\text { cultivation }\end{array}$ & 55 & 91.66 \\
\hline 33 & Do you know chemicals are also added for improving mushroom cultivation & 59 & 98.33 \\
\hline 35 & Whether Dhingri mushroom is grown in your locality & 60 & 100 \\
\hline 35 & Oyster is comparatively easy in cultivation & 60 & 100 \\
\hline 36 & Do you know which disease affects mushroom cultivation & 51 & 85 \\
\hline 37 & Does any insect pest attack cultivation of mushroom & 14 & 23.33 \\
\hline 38 & Spawn is attacked by disease, insects and pests & 38 & 63.33 \\
\hline 39 & Do you use any control measure for controlling the disease & 23 & 38.33 \\
\hline 40 & Clean knife and gloves should be used for mushroom production & 9 & 15 \\
\hline 41 & Do you clean the knives and gloves after use and dry them & 50 & 83.33 \\
\hline 42 & Do you preferred to process your mushroom before the sale & 59 & 98.33 \\
\hline 43 & Do you process mushroom yourself at your house & 56 & 93.33 \\
\hline 44 & Does processing fetch you a more remunerative price & 50 & 83.33 \\
\hline 45 & Do you want to sell your product in the local market, big market, or city market & 60 & 100 \\
\hline 46 & Do you get remunerative price for your product at local market or city market & 10 & 16.66 \\
\hline
\end{tabular}




\begin{tabular}{|c|c|c|c|}
\hline & & & \\
\hline 47 & Do you get help with any agency in the marketing & 2 & 3.33 \\
\hline 48 & $\begin{array}{l}\text { Have you formed any co-operative society for marketing as well as other } \\
\text { purposes to grow mushroom }\end{array}$ & 56 & 93.33 \\
\hline 50 & Can you store your fresh produce for a week & 6 & 10 \\
\hline 51 & Do you know about spawn & 60 & 100 \\
\hline 52 & Do you know about the method of spawn preparation & 58 & 96.66 \\
\hline 54 & Do you know about disease attacks more in spawn bags & 17 & 28.34 \\
\hline 55 & Do you know about suitable temp for spawn production & 32 & 53.34 \\
\hline 56 & Do you know about the spawn rate for mushroom cultivation & 44 & 73.34 \\
\hline
\end{tabular}

Table 5: Knowledge Level of Women Mushroom Growers

\begin{tabular}{llll}
\hline Sl. No. & Category & Frequency & Percentage \\
\hline 1 & Low (Mean - SD) & 7 & 11.67 \\
2 & Medium (Mean \pm SD & 45 & 75.00 \\
3 & High (Mean + SD) & 8 & 13.33 \\
\hline Total & & $\mathbf{6 0}$ & $\mathbf{1 0 0}$ \\
\hline
\end{tabular}

component of mushroom cultivation and has been presented in Table 3.

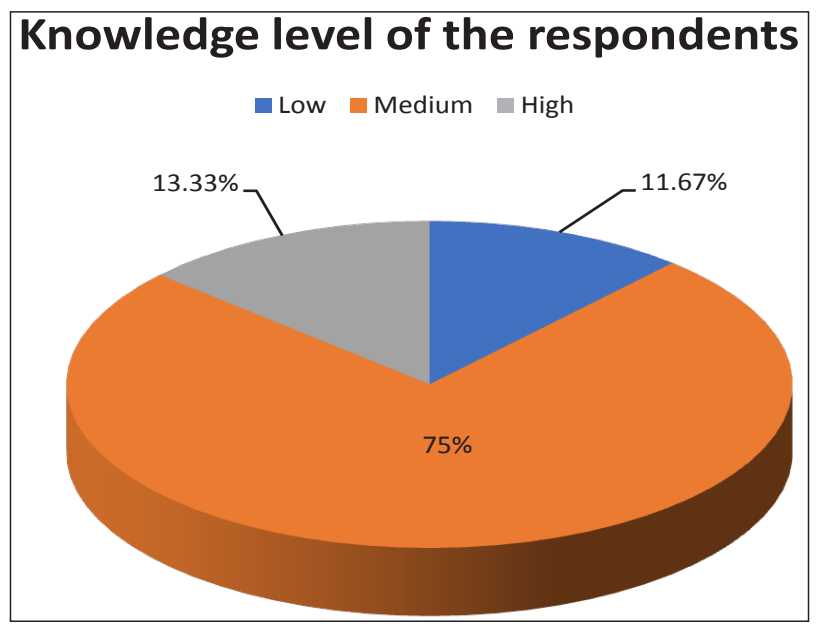

Fig. 1: Distribution of Respondents according to their knowledge level

To assess the impact of mushroom cultivation on the sustainability of women mushroom growers' attitude about mushroom cultivation of the respondents was studied. Based on calculated of statements given by the respondents was classified into three categories i.e., Least favorable (up to 15), favorable (16-19), and most favorable (Above 19) level of attitude, which is presented here in Table 3.

It is evident from Table 6 that out of sixty respondents' maximum respondents $(73.33 \%)$ had favorable attitude scores ranging from 16-19, which indicated that they possessed a favorable attitude towards mushroom cultivation. A similar finding was reported by Jahan et al. (2010), who also found that majority of respondents had a favorable attitude towards mushroom cultivation.

Table 6: The attitude of Women Mushroom Growers $(n=60)$

\begin{tabular}{|c|c|c|c|}
\hline $\begin{array}{l}\text { Sl. } \\
\text { No. }\end{array}$ & Category & Frequency & Percentage \\
\hline 1 & Least Favourable & 7 & 11.67 \\
\hline 2 & Favourable & 44 & 73.33 \\
\hline 3 & Most Favourable & 9 & 15 \\
\hline Total & & 60 & 100 \\
\hline
\end{tabular}

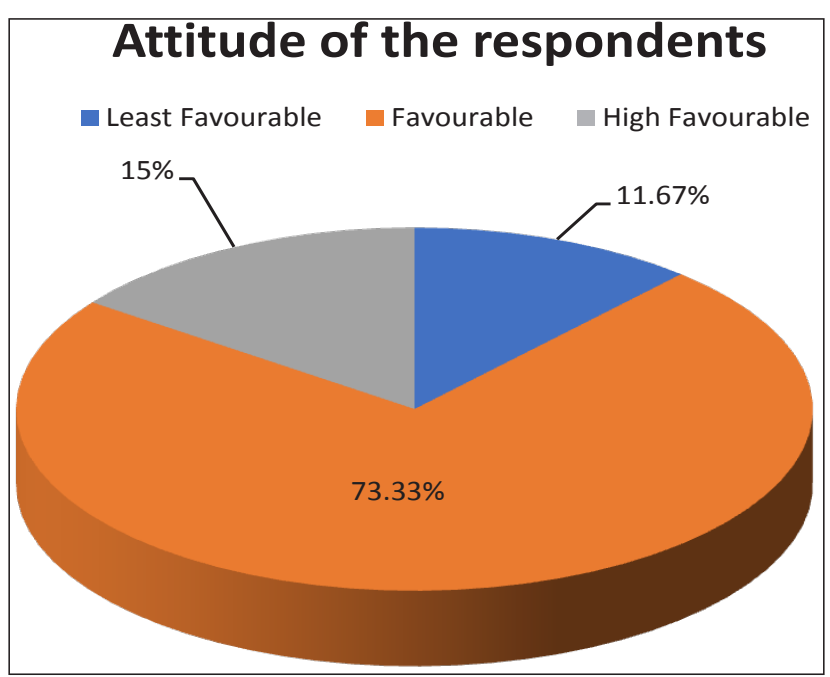

Fig. 2: Distribution of Respondents according to their attitude level 


\section{CONCLUSION}

The present research work has shown that women play a significant role in mushroom cultivation and can use their leisure for profitable ventures. After training, 75 percent of women have shown a medium level of knowledge regarding mushroom cultivation, while 73.33 percent of women have shown a favorable attitude for mushroom farming and count it as a sustainable method of employment and income generation. This level of knowledge and attitude might be due to the extensive training and workshops conducted by the training centers. The research work has also revealed that the women mushroom cultivators are facing the problem of storage, proper harvesting techniques, declination in nutritional value, and lack of agencies for marketing of their products. Hence, these problems open the scope for future research work in mushroom cultivation, making a venture of less capital investment and high-income generation.

\section{REFERENCES}

Jahan, N., Moonmoon, M. and Shah, M. 2010. Grower's response to mushroom cultivation technologies disseminated by mushroom development project. J. Agric. Soc. Sci., 6(4): 96-100.

Kavitha, K., Latha, R., Hassan, S.N. and Thirukumaran, K. 2019. Impact of Skill Development Training on Mushroom Cultivation in Kanyakumari District of Tamil Nadu. J. Krishi Vigyan, 7(2): 144.

Mazumdar, H., Neog, M., Deka, M., Bhattacharyya, S., Sarma, U.J., Ali, A. and Rajbongshi, A. 2020. Impact of Training on Mushroom Cultivation for Women Entrepreneurship Development, 8(4): 1287-1290.

Nagaraj, R., Arunkumar, P., Hanumanthaswamy, B.C. and M. Rathod, J. 2017. Mushroom Production for SelfEmployment - An Impact Study. Int. J. Curr. Microbiol. Applied Sci., 6(8): 2991-2997.

Rachna, R.G. and Sodhi, G.P.S. 2013. Evaluation of vocational training programmes organized on mushroom farming by Krishi Vigyan Kendra Patiala. J. Krishi Vigyan, 2(1): 26-29.

Shahi, V., Shahi, B. and Singh, K.M. 2018. Impact study on mushroom cultivation for micro entrepreneurship development and women Empowerment Soil water plant Health View project Regional Crop Planning for improving resource use efficiency and sustainabily View project. J. Pharmacogn. Phytochem., SP4: 01-04. 